\title{
Adaptation to climate change: Genetic variation is both a short- and a long-term solution
}

\author{
by Jean Beaulieu ${ }^{1}$ and André Rainville ${ }^{2}$
}

\begin{abstract}
We propose a methodology combining a biophysical site index model and a seed source transfer model based on both temperature and precipitation to estimate white spruce plantation yield under present and future global warming conditions. The biophysical site index model predicts dominant height at 25 years, which is further used to estimate plantation yield using yield tables. The transfer model shows that, on average, seed sources are best adapted to the temperature conditions where they presently grow, and give maximum yield under these conditions. However, this model also shows that transfer of seed sources to drier sites could improve plantation yield. To predict site index values under climate change conditions, values obtained from the biophysical site index model are corrected by a factor estimated using the seed source transfer model. Our simulation results predict that global warming should favour a slight increase in white spruce plantation yield in southern Québec. However, one cannot expect to obtain similar yields from a seed source rapidly exposed to warmer conditions compared with a seed source that is presently growing under climatic conditions to which it has become adapted. It would take several generations (adaptation lag) for a seed source to adapt to warmer conditions. We believe that the method we propose will be helpful in identifying the most productive seed source to be used at any given location in the province, and in revising seed source transfer rules.
\end{abstract}

Key words: climate change, white spruce, provenance test, transfer model, site index, adaptation, plantation, GIS

\section{RÉSUMÉ}

Nous proposons une méthodologie qui combine un modèle d'indice de station biophysique et un modèle de transfert des sources de semences reposant à la fois sur la température et les précipitations afin d'estimer le rendement d'une plantation d'épinette blanche en fonction des conditions actuelles et futures selon un réchauffement global. Le modèle d'indice de station biophysique prédit la hauteur dominante à lâge de 25 ans qui est utilisé par la suite pour estimer le rendement d'une plantation au moyen de tables de rendement. Le modèle de transfert indique, qu'en moyenne, les sources de semences sont mieux adaptées aux conditions climatiques là où elles croissent actuellement et atteignent un rendement maximum sous ces conditions. Cependant, ce modèle indique également que le transfert de sources de semences vers des stations plus sèches pourrait accroître le rendement de la plantation. Pour prévoir les valeurs de l'indice de station dans le cas de changements climatiques, les valeurs obtenues du modèle d'indice de station biophysique sont corrigées par un facteur estimé au moyen du modèle de transfert des sources de semences. Les résultats de nos simulations prédisent que le réchauffement planétaire pourrait entraîner une légère augmentation du rendement des plantations d'épinette blanche du sud du Québec. Toutefois, on ne peut s'attendre à obtenir des rendements semblables d'une source de semences exposée rapidement à des conditions plus chaudes comparativement à une source de semences qui se développe présentement sous des conditions climatiques auxquelles elle s'est adaptée. Il faudra plusieurs génération (délai d'adaptation) à une source de semences pour s'adapter à des conditions plus chaudes. Nous considérons que la méthode que nous proposons sera utile pour identifier les sources les plus productives de semences qui pourraient être utilisées partout dans la province et pour réviser les directives de transfert des sources de semences.

Mots clés : changements climatiques, épinette blanche, test de provenance, modèle de transfert, indice de station, adaptation, plantation, SIG

\footnotetext{
${ }^{1}$ Natural Resources Canada, Canadian Forest Service, Laurentian Forestry Centre, 1055 du P.E.P.S., P.O. Box 3800, Sainte-Foy, Quebec G1V 4C7. E-mail: JBeaulieu@cfl.forestry.ca

${ }^{2}$ Ministère des Ressources naturelles et de la Faune du Québec, Direction de la recherche forestière, 2700, rue Einstein, Sainte-Foy (Québec) G1P 3W8.
} 


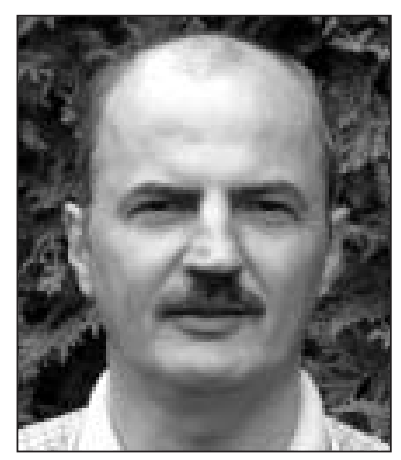

Jean Beaulieu

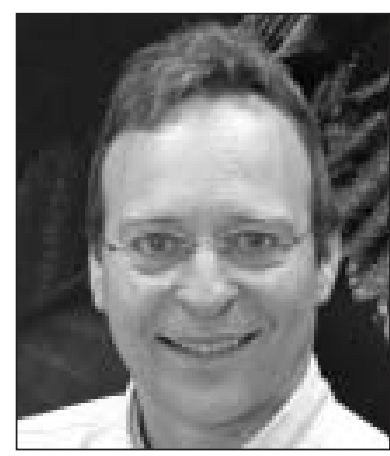

André Rainville

\section{Introduction}

The impacts of climate change are often looked at in terms of effects on ecosystems and species. Rising ocean levels as well as the nutrition and reproduction of polar bears are two striking examples. Genetic diversity is seen as an insurance policy as it provides species with both adaptation and evolution capacities, thus offsetting environmental change effects (Lynch and Walsh 1998). Fortunately, forest tree species are amongst the most diverse living organisms, being respectively $38 \%$ and $50-80 \%$ more diversified than annual plants and all other forms of life (Hamrick et al. 1992). Genetic tests established in the past few decades provide us with the opportunity to quantify genetic diversity in adaptive traits, to measure the performance of a given provenance when transferred to different environments, and to simulate the effect of climate change.

\section{Genetic Variation in Tree Species}

Wide ranging species such as spruces and pines are structured in more or less independent groups called populations, in which individuals have the possibility to interbreed. Progeny that are ill-adapted to environmental conditions (climate, soil, competition, etc.) are eliminated through a process of natural selection. Because adaptive traits are modeled by both genes and environment, common garden tests must be set up to estimate the proportion of variation explained by each of these factors (Nanson 2004). By comparing the performance of individual provenances in common garden tests replicated over a variety of environments, one can evaluate the response of these provenances to varying climatic and soil conditions (Carter 1996, Matyas 1996). Similarly, the response of a given provenance to climate change can be simulated using a transfer model relating the performance of the provenance to temperature and/or precipitation differences existing between the common garden test sites and those of provenance or seed source origin.

Wide-ranging species display a high level of genetic variation in morphological characteristics and adaptive traits within and between populations. Due to this variation, these species have some capacity to adapt to new selection pressures from climate change (Beaulieu et al. 2001). Differences among populations for adaptive traits can generally be explained by their geographic location and environmental factors. Variation modeled by geographical and environmen- tal gradients is called clinal variation (Morgenstern 1996) and has been shown for many species such as black spruce (Beaulieu et al. 2004) and white spruce (Li et al. 1997). Populations are thus adapted to their local environment but if the climate changes, their performance will be affected either positively or negatively and can be largely predicted.

Tuhkanen (1980) showed that climate is the key environmental factor responsible for large-scale distribution of living organisms; therefore, it is reasonable to conclude that forest ecosystems will be widely affected by climate change. Changes could operate at two levels: ecosystems and populations (Bazzaz et al. 1995, Bawa and Dayanandan 1998). Species are structured in populations adapted to local environmental conditions, as mentioned before, and genetic and evolutionary forces act at the population level. This is why we are interested here in evaluating the potential impact of climate change on populations or provenances.

From an economic viewpoint, it is as important to estimate the adaptation capacity of a species so as to predict the impact of climate change on its yield. Here we report on a methodology we used to estimate plantation yield under global warming conditions. First, a biophysical site index model was developed using data collected in commercial, as well as experimental plantations. This model was then used in connection with a seed source transfer model produced by Andalo et al. (2005) for white spruce. Third, plantation yield was estimated using tables published by Bolghari and Bertrand (1984). In this paper, we present the methodology and some examples of potential impacts for white spruce, a high-yield species widely used in reforestation programs in Québec (Masse 1999).

\section{White Spruce Plantation Yield in Québec under Pre- sent Climate Conditions}

The white spruce plantation yield tables used in Québec were developed for southern Québec by Bolghari and Bertrand in 1984, and partially updated by G. Prégent (personal communication). To obtain an estimate of plantation yield for a given site at a given age, the site index (SI) and spacing between trees must be known. Yield estimates can be obtained for SI varying from $6 \mathrm{~m}$ to $12 \mathrm{~m}$ at 25 years. Ung et al. (2001) suggested that SI could be estimated for any site using a biophysical site index model. Following the methodology of Ung et al. (2001), this biophysical site index model was developed using growth data from more than 600 plantations monitored by the Ministère des Ressources naturelles et de la Faune du Québec, and climatic variables generated by BioSIM (climate simulation software developed at the Canadian Forest Service (Régnière 1996)). Among the climatic variables tested, (degree-days, aridity index, summer precipitation, cumulative vapour pressure deficit and soil water-holding capacity), linear components of degree-days and summer precipitation were the only statistically significant variables. This model makes it possible to estimate SI and, in combination with yield tables, the yield of any white spruce plantation in southern Québec as long as degree-days and summer precipitation at the plantation site are known. For instance, 50-year-old plantation yield predicted for southern Québec under the current climate conditions is presented in Fig. 1. 


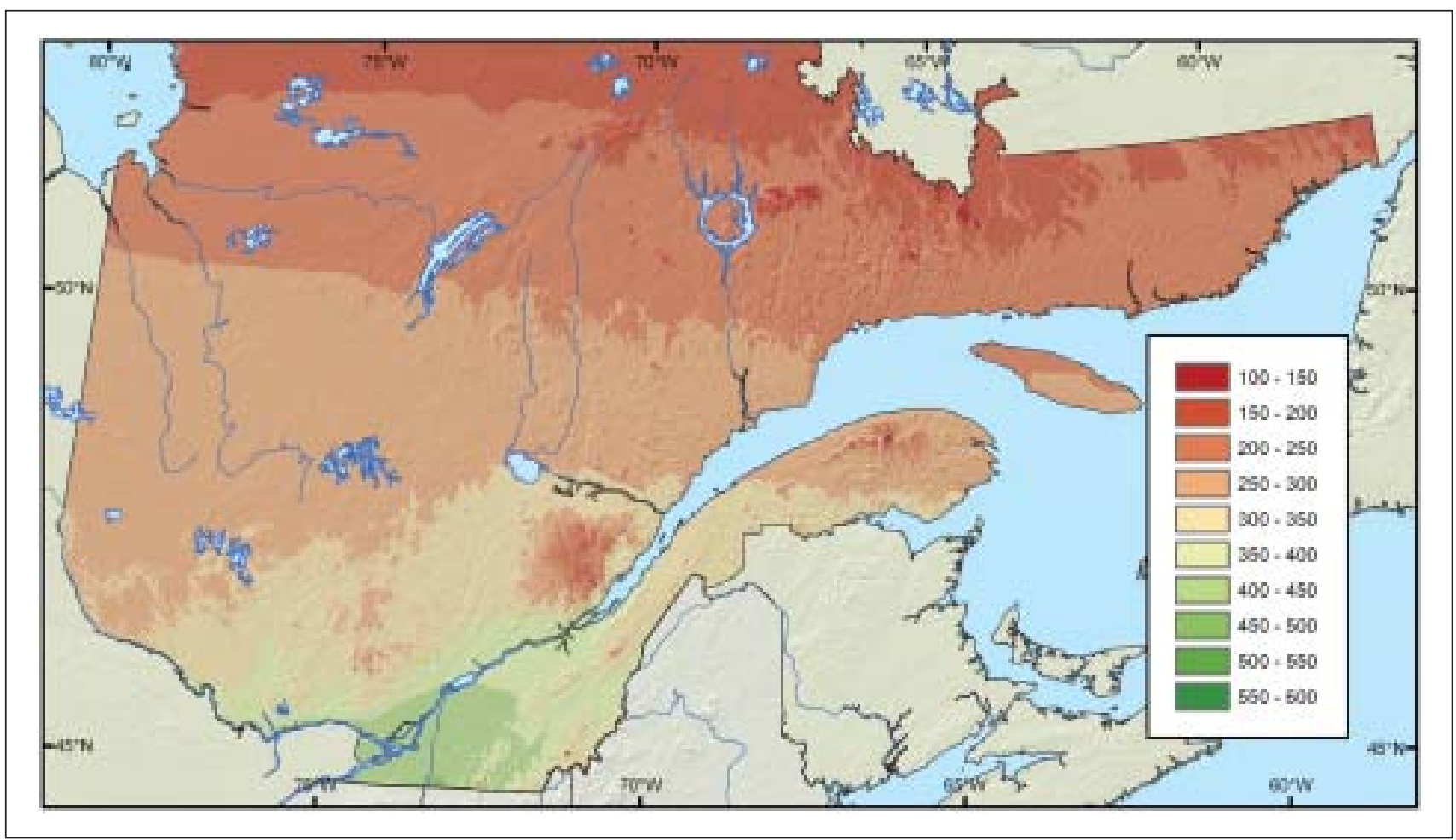

Fig. 1. Fifty-year-old white spruce plantation predicted yield (2.24 m spacing) under current climate conditions in Québec. Figures are in cubic metres per hectare.

\section{Impacts of Climate Change on White Spruce Plantation Yield in Québec}

Assuming the biophysical SI model described above is still valid under global warming conditions, the yield of a plantation growing under the new environmental conditions resulting from climate change could be predicted for every site in Québec if climatic data (temperatures and precipitation) predicted by general circulation models are available. These predictions for doubling $\mathrm{CO}_{2}$ levels over the next 100 years were recently integrated into the BioSIM simulation software and this allowed us to map plantation yield in the province of Québec up to 2070. However, before beginning the process, adjustments must be made to site index estimates to take into account the fact that forest tree species cannot adapt within a generation to rapid environmental changes such as global warming.

Analysis of provenance test data makes it possible to develop models that can help estimate the impact of climate change on forest tree growth. This was done by Andalo et al. (2005) for white spruce height with data collected in a 22-year-old white spruce provenance test. This test was replicated on three sites in Québec, i.e., La Patrie, Mastigouche and Dablon, along a latitudinal transect (from latitude $45^{\circ} 20^{\prime}$ to $48^{\circ} 21^{\prime}$ ). Forty-five provenances were tested, each represented by five open-pollinated families in a randomized complete block design with six replications per site and five-tree row plots. A total of 15436 trees were measured. Andalo et al. (2005) reported that the relative performance of the provenances was weakly statistically influenced by site (interaction site by provenance) and thus developed a transfer model that can be utilized across southern Québec. This was a temperature-precipitation transfer model. Seven climatic variables (five for temperature and two for precipitation) were tested. Of the five temperature variables tested, mean maximum daily temperature explained the greatest proportion of variation. Adding total summer precipitation to the regression model as an independent variable made it possible to explain 34\% of total variation among populations. Similar results were also reported for Norway spruce and black spruce (Mäkinen et al. 2000, Beaulieu et al. 2004). The transfer model showed that, on average, optimal performance was at locations where temperature matches that of the seed source location. As a result of this, a seed source planted in an environment that is colder or warmer than that of its origin is not expected to perform at the same level as a seed source that is already adapted to this environment. It could require several generations, during which natural selection occurs, for this seed source to have a productivity level similar to that of a provenance already adapted to its temperature regime. The model also suggested that moving seed sources to drier sites would on average allow them to increase their productivity. A tendency to occupy suboptimal environments has already been reported for other species such as Pinus contorta (Rehfeldt et al. 1999).

To obtain realistic estimates of white spruce plantation yield for a given seed source at any site after climate change, we suggest adjusting SI estimates using the results of transfer models (see Fig. 2) such as the one developed by Andalo et al. (2005). Existing yield table and GIS tools can then be used to map plantation yield. This is what we did using Bolghari and Bertrand (1984) white spruce yield tables. These maps show 


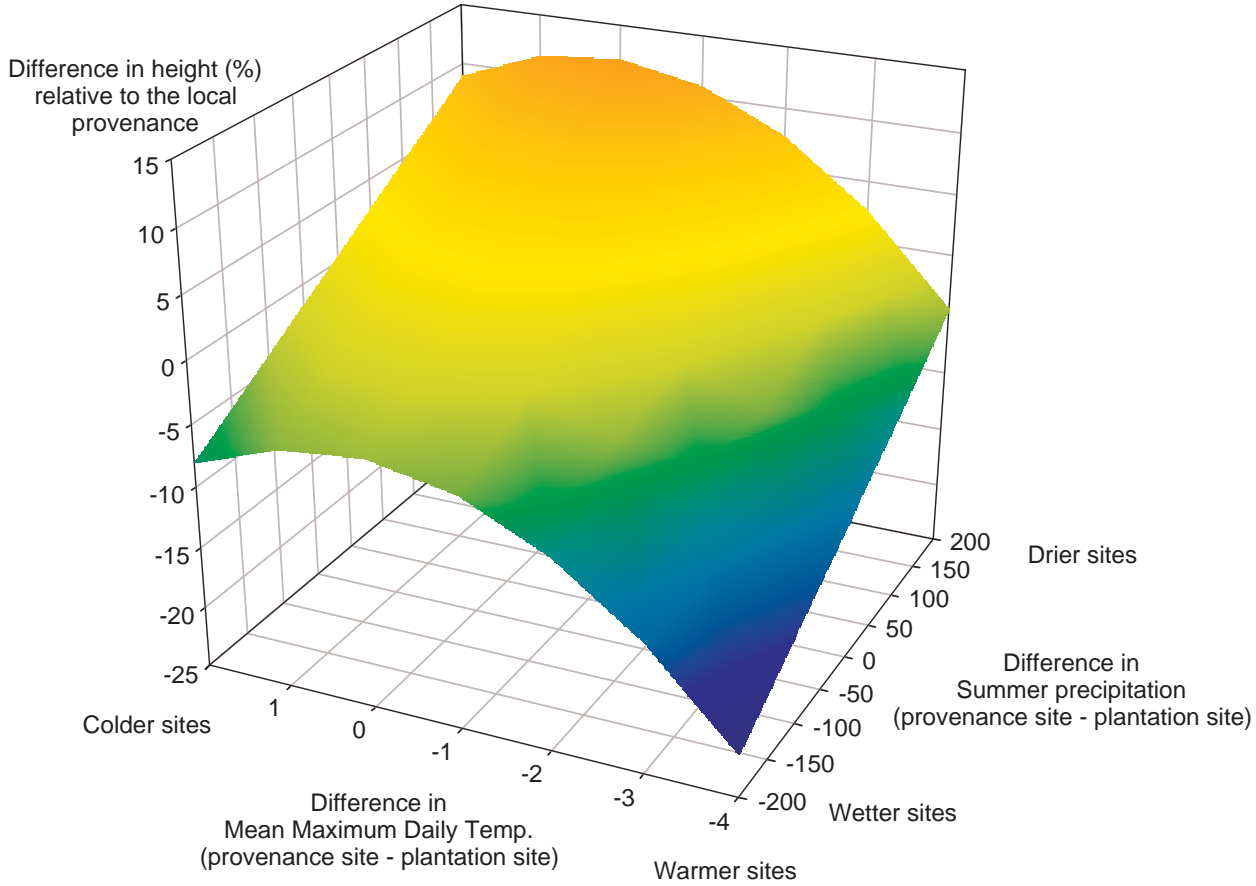

Fig. 2. Difference in height of a given white spruce provenance relative to the local one as a function of the difference in maximum daily temperature and summer precipitation between the provenance site and the plantation site where the local provenance grows ladapted from Andalo et al. 2005).

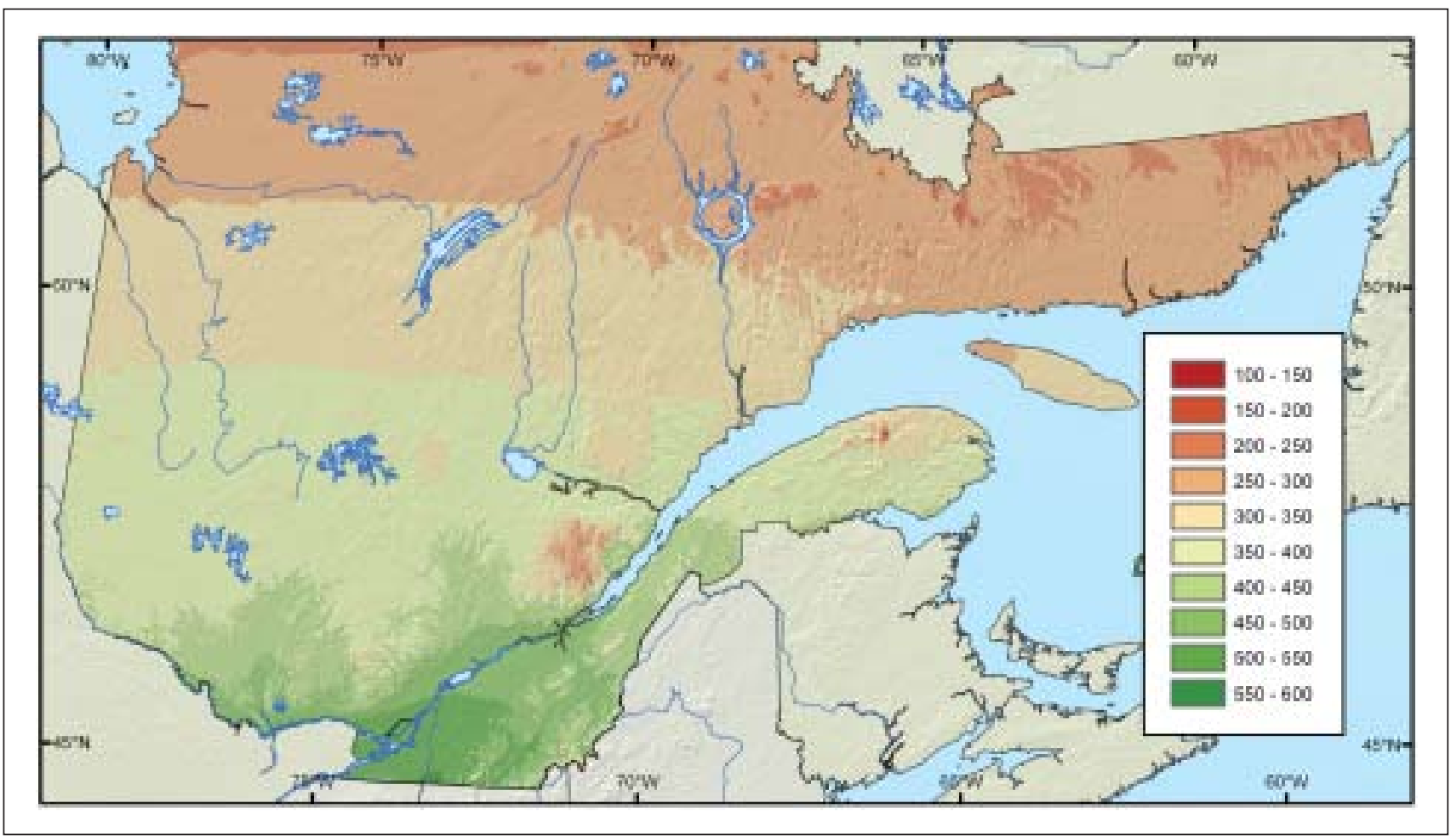

Fig. 3. Fifty-year-old white spruce plantation predicted yield (2.24 m spacing) for 2070 in Québec when site index is not adjusted for the adaptation lag ensuing from rapid global warming. Figures are in cubic metres per hectare. 


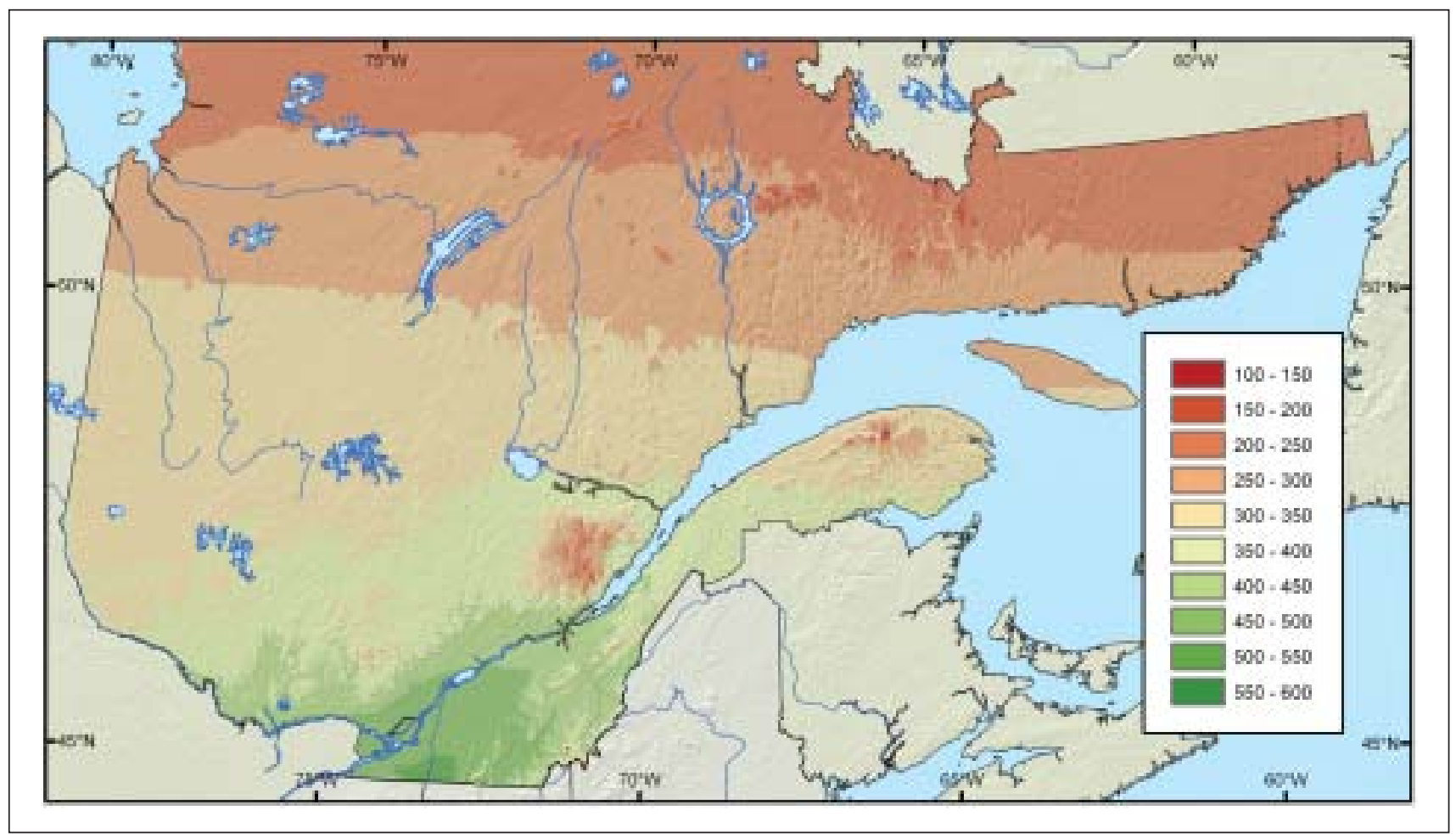

Fig. 4. Fifty-year-old white spruce plantation predicted yield ( 2.24 m spacing) for 2070 in Québec adjusted for the adaptation lag ensuing from rapid global warming. Figures are in cubic metres per hectare.

that under climate change, white spruce plantation yield would still increase, but not as rapidly as estimated without taking into account the adaptation lag (Fig. 3 and 4). In 2070, for example, this increase should be in the order of $10 \%$ to $15 \%$ compared with current productivity, assuming that the models are still valid and interactions with biotic factors are unchanged.

According to general circulation models and the hypothesis of doubling $\mathrm{CO}_{2}$ levels over the next 100 years, the regions of the Mastigouche wildlife reserve (sugar maple-yellow birch bioclimatic region) and of Témiscouata (balsam fir-yellow birch bioclimatic region) would be $2^{\circ} \mathrm{C}$ warmer in 2070; their climates would become somewhat equivalent to that presently prevailing in the Montréal region (Mirabel). White spruce plantation yields in these two regions would be in the range of $350-400 \mathrm{~m}^{3}$ per hectare at 50 years of age, which is approximately $50 \mathrm{~m}^{3}$ lower than the actual average plantation yield in the Montréal region (400-450 $\mathrm{m}^{3} / \mathrm{ha}$ ). This example shows that while the productivity of plantationgrown white spruce should increase under climate change conditions, the rapidity of this increase is not expected to match that of climate change.

\section{Practical Implications: Choice of Seed Sources for the Reforestation Program}

Models developed to predict white spruce plantation yield and integrated into the BioSIM simulation software could also be used to identify the best seed sources for a given reforestation site with the aim of maximizing yield. We simulated the transfer of two seed sources, the first one from Valcartier, located in the balsam fir-yellow birch bioclimatic region north of Quebec City (latitude $46^{\circ} 54^{\prime}$, longitude $71^{\circ} 30^{\prime}$ ) and the second one, the first-generation Labrosse seed orchard, also located in the balsam fir-yellow birch bioclimatic region but near the Saguenay River (latitude $49^{\circ} 20^{\prime}$, longitude $69^{\circ}$ $\left.7^{\prime}\right)$, to any site in Québec. We compared predicted 50-year yield of these two seed sources with that of local seed sources.

Hence, based on the models described herein, a plantation established in the Montréal region with trees from Valcartier is expected to produce, at 50 years of age, a yield similar to that of local provenances $\left(400-450 \mathrm{~m}^{3} / \mathrm{ha}\right)$ under present climate conditions. However, in 2070 with the prevailing climatic conditions at that time, its yield is expected to be lower than that of local provenances (380-426 vs. $\left.450-500 \mathrm{~m}^{3} / \mathrm{ha}\right)$. On the other hand, if the plantation of Valcartier seedlings was established in the Témiscouata region, its yield would be greater than that of the local provenances under present climate conditions $\left(400-425\right.$ vs. $300-350 \mathrm{~m}^{3} / \mathrm{ha}$ ), and would still be greater in $2070\left(400-425\right.$ vs. $\left.350-400 \mathrm{~m}^{3} / \mathrm{ha}\right)$. These examples show that the transfer of a seed source could be beneficial in some situations, but not in others.

As a second example, we estimated the yield of 50-year-old plantations established with Labrosse seed orchard seedlings on two sites, the first one northwest of Baie-Comeau (balsam fir-white birch ecological region) and the second one in the Témiscouata region. Both of these planting sites are located in the zone determined by tree breeders as being suitable for the use of seeds from the Labrosse seed orchard. Under the present climatic conditions, our models predict that plantation yield would be similar using either seedlings from the Labrosse seed orchard or from local sources, i.e., 250-300 $\mathrm{m}^{3} / \mathrm{ha}$ and $300-350 \mathrm{~m}^{3} / \mathrm{ha}$ for Baie-Comeau and 
Témiscouata, respectively. The same situation would continue to be valid in 2070 , with $300-350 \mathrm{~m}^{3} / \mathrm{ha}$ in the BaieComeau region, and $350-400 \mathrm{~m}^{3} / \mathrm{ha}$ in the Témiscouata region.

\section{Conclusions}

Experimental plantations established by forest geneticists in a variety of environments in Québec have provided us with an opportunity to acquire information on the potential impact of climate change on white spruce plantation yield in that province. Three observations emerged from the study:

- In Québec, performance of plantations should slightly increase with climate change if current interactions with biotic and abiotic factors do not change.

- Local populations are not expected to take full benefit of these new conditions. It could take several generations before they are fully adapted. Due to this adaptation lag, production in populations submitted to warmer conditions will be lower than that observed in populations already growing under these climate conditions.

- Based on our simulations, the actual transfer rules for reforestation material should still be valid for the climate conditions of the next 50 years.

Our understanding regarding the potential impact of climate change on the different factors affecting plantation yield is far from complete (e.g., capacity of soils to support a yield increase, changes in competition, fire frequencies and pest outbreaks, etc.). Extensive research work must still be carried out to obtain more accurate estimates of these impacts. However, the methodology proposed herein for white spruce, partly based on the research work of Andalo et al. (2005), should help us to obtain an initial approximation of these impacts and to verify whether the seed zones delineated for each seed orchard should be modified. Better precision in these estimates would probably be obtained by setting up new provenance tests replicated on a larger number of sites covering all the area where white spruce is planted.

\section{Acknowledgements}

The authors are grateful to Dr. Christophe Andalo from Université Paul-Sabatier, France, and Dr. Jean Bousquet from Université Laval for sharing data on the white spruce transfer model. They also thank Dr. Frédéric Raulier from Université Laval and Mr. Guy Prégent from the Ministère des Ressources naturelles et de la Faune du Québec for their contribution to the development of the biophysical site index model. They are also indebted to Dr. Jacques Régnière and Mr. Rémi St-Amant from the Canadian Forest Service for the development of a BioSIM software application to predict plantation yield under present climate conditions and future global warming. They also thank Ms. Pamela Cheers for her editorial work, Mr. Pierre Duval for preparing the figures and Mr. Gaëtan Daoust for his revision of a preliminary version of this manuscript. This research was supported by grants from the Ministère des Ressources naturelles et de la Faune du Québec, the Canadian Forest Service, and the Fonds Québécois de la Recherche sur la Nature et les Technologies (F.Q.R.N.T.).

\section{References}

Andalo, C., J. Beaulieu and J. Bousquet. 2005. The impact of climate change on growth of local white spruce populations in Québec, Canada. Forest Ecology and Management 205: 169-182.

Bawa, K.S. and S. Dayanandan. 1998. Global climate change and tropical forest resources. Climate Change 39: 473-485.

Bazzaz, F.A., M. Jasienski, S.C. Thomas and P. Wayne. 1995. Microevolutionary responses in experimental populations of plants to $\mathrm{CO}_{2}$-enriched environments: Parallel results from two model systems. Proceedings of the National Academy of Sciences USA 92: 8161-8165.

Beaulieu, J., M. Perron and J. Bousquet. 2004. Multivariate patterns of adaptive genetic variation and seed source transfer in Picea mariana. Canadian Journal of Forest Research 34: 531-545.

Beaulieu, J., A. Rainville, G. Daoust and J. Bousquet. 2001. La diversité génétique des espèces arborescentes de la forêt boréale. Le naturaliste canadien 125: 193-202.

Bolghari, H.A. and V. Bertrand. 1984. Tables préliminaires de production des principales essences résineuses plantées dans la partie centrale du sud du Québec. Ministère Énergie et Ressources du Québec, Direction Recherche forestière, Mémoire de recherche forestière No 79.

Carter, K.K. 1996. Provenance tests as indicators of growth response to climate change in 10 north temperate tree species. Canadian Journal of Forest Research 26: 1089-1095.

Hamrick, J.L., M.J.W. Godt and S.L. Sherman-Broyles. 1992. Factors influencing levels of genetic diversity in woody plant species. New Forests 6: 95-124.

Li, P., J. Beaulieu and J. Bousquet. 1997. Genetic structure and patterns of genetic variation among populations in eastern white spruce (Picea glauca). Canadian Journal of Forest Research 27: 189-198.

Lynch, M. and B. Walsh. 1998. Genetics and analysis of quantitative traits. Sinauer Assoc. Inc., Sunderland, MA. 980 p.

Mäkinen, H., P. Nöjd and K. Mielikäinen. 2000. Climatic signal in annual growth variation of Norway spruce (Picea abies) along a transect from central Finland to the Arctic timberline. Canadian Journal of Forest Research 30: 769-777.

Masse, L. 1999. La production de matériel amélioré génétiquement. Les vergers à graines (voie sexuée). Dans Actes du colloque L'amélioration génétique en foresterie : où en sommes-nous ? Rivière-du-Loup, 28-30 septembre 1999. pp. 117-123.

Matyas, C. 1996. Climate adaptation of trees: rediscovering provenance tests. Euphytica 92: 45-54.

Morgenstern, E.K. 1996. Geographic variation in forest trees. Genetic basis and application of knowledge in silviculture. UBC Press, Vancouver, BC. 209 p.

Nanson, A. 2004. Génétique et amélioration des arbres forestiers. Les Presses agronomiques de Gembloux, Gembloux, Belgique. 712 p.

Régnière, J. 1996. Generalized approach to landscape-wide seasonal forecasting with temperature-driven simulation models. Environmental Entomology 25: 869-881.

Rehfeldt, G.E., C.C. Ying, D.L. Spittlehouse and D.A. Hamilton. 1999. Genetic responses to climate in Pinus contorta: niche breadth, climate change, and reforestation. Ecological Monographs 69: 375-407.

Tuhkanen, S. 1980. Climatic parameters and indices in plant geography. Acta Phytogeographica Suecica 67: 1-105.

Ung, C.-H., P.Y. Bernier, F. Raulier, R.A. Fournier, M.-C. Lambert and J. Régnière. 2001. Biophysical site indices for shade tolerant and intolerant boreal species. Forest Science 47(1): 83-95. 